\title{
THE PROCESS OF FORMING A CRIMINAL POLICY OF THE EUROPEAN UNION
}

\author{
Marin Petkov ${ }^{1}$ and Dragomir Krastev ${ }^{2}$, \\ ${ }^{1}$ Assoc. Professor, Ph.D., National Military University, Veliko Tarnovo, Bulgaria, \\ marin_5kov@abv.bg \\ ${ }^{2}$ Assoc. Professor, Ph.D., National Military University, Veliko Tarnovo, Bulgaria, \\ drago.krastev@gmail.com
}

\begin{abstract}
The formation of a punitive policy is a historic process that arises in the first state-run societies of Sumer and Assyro-Babylonia and develops simultaneously with the improvement of political and state organization.

Outstanding merit for the formation of modern criminal policy, criminal law and criminology is Cesare Becaria. In 1763, he published his work: „Crime and Punishment“, triggering criminology and criminal policy.

Keywords: Policy, Criminal policy, Criminality Principles of criminal policy.
\end{abstract}

\section{INTRODUCTION}

Organised crime is a serious crime committed by organized crime groups that often has a transnational dimension that requires the cooperation of the EU institutions and their Member States with Third countries and international organisations. This organised crime challenges the traditional definition of organised crime since it is now responding to a new market order. Organised crime criminals act as brokers providing highly specialized services to customers throughout the world, communicating through new technologies of information and escaping the traditional forms of crime prevention and repression. At the same time, these criminals are easily replaceable. Their structures are challenging criminal and administrative approaches to dismantle their networks.

\section{THE PROCESS OF FORMING A CRIMINAL POLICY OF THE EUROPEAN UNION}

Historical background

The cooperation in criminal matters between the Member States had its beginning in 1975. Then, during the meeting of European Council, an informal group - TREVI (Terrorism, Radicalism, Extremism, and Violence International) was established. TREVI was the forum of the operational cooperation between ministries of justice and internal affairs of the Member States. It functioned till the entering into force of TEU. The next 
step to improve the cooperation has constituted the Schengen Treaty of 14 June 1985, executed through Schengen Convention of 19 June 1990. It is crucial to remember that did not only eradicate the border 2 control between The Member States but also provided for the deepening of the cooperation in the area of the fight against criminal behaviours as well as the broadening of the operational cooperation. Clearly, the cooperation of European states in the area of penal law goes further than the EU; however it was the Maastricht Treaty which for the first time regulated the questions of justice system and internal affairs. Since its adoption, the Union was based on, so called, three pillars - the third one was devoted to police and judicial cooperation in criminal matters. One of the principal goals of the EU is the creation and realization of the "space of freedom, security and justice", with the crucial role of Council and Commission (Article 3(2), Article $11 \mathrm{TEU}$ ). The European Judicial Area constitutes an element of the "space of freedom, security and justice" and covers the cooperation in both criminal and civil matters. The Title VI of the TEU established the cooperation in criminal matters as a subject of the intergovernmental cooperation. The common framework included the police and judicial cooperation in criminal matters and the prevention and combat against racism and xenophobia (Article $29 \mathrm{TEU}$ ). The judicial cooperation intended to facilitate and accelerate the cooperation between competent ministries and judicial or equivalent authorities of the Member States with regard to judicial proceedings and the enforcement of judicial decisions. It also aimed at the facilitation of extradition between the Member States, the approximation of the criminal norms of the Member States, the prevention of the jurisdictional conflicts and, finally, the adoption of measures establishing minimum rules relating to the constituent elements of criminal acts and to penalties in the fields defined by the TEU (Article 31 TEU). Under the Maastricht Treaty three different instruments could be adopted in the third pillar: common positions, common activities and conventions. The conventions, as treaties governed by public international law had appeared to be ineffective, as they were not ratified by all Member States. Furthermore, the ratification procedure was protracted. Also, the other instruments of the third pillar appeared to be insufficient. The closer contacts between the Member States required the introduction of the more effective instruments. In the search for the adequate solutions, the Amsterdam Treaty (which entered into force on 1 May 1999) introduced a framework decision as a specific instrument of the third pillar. Furthermore, during the European Council in Tampere in 1999 five-year program of actions was adopted. Its major aims were: to guarantee the freedom of movement of persons, to establish the security for the EU citizens, to facilitate the access to the justice system and the mutual recognition of judicial decisions and their effective implementation on the territory of the EU Member States. Despite these challenging goals, again it proved to be complicated to create effective framework of cooperation. Subsequent five-year program of action (the Hague program) of 2005 aimed also in the strengthening of the cooperation between the Member States. The closer cooperation was considered as a device for the assurance of fundamental rights and the minimal procedural guarantees as well as the access to justice; the fight against transnational organized crime and the prevention of terrorist threats; the continuation of the mutual recognition of judicial decisions in civil and criminal matters. Unfortunately, also this initiative did not introduce any considerable institutional changes that could positively affect the effectiveness of the Member States cooperation. Before the Lisbon reform, under Article 34 TEU, to achieve the aims of the Union, the Council could utilize certain measures. The Council could adopt common positions, framework decisions to approximate the legal regulations in the Member States, decisions to achieve the other goals and conventions recommended to be adopted by the Member States. However, also these solutions provided evidence to be inadequate for the approximation of the Member States" legal systems. Therefore, the next step has been undertaken with the adoption of the Lisbon Treaty.

\section{Offences relating to participation in a criminal organisation}

The Framework Decision offers in its Article 1 definitions of criminal organisation and structured association that follows closely those of the UN Organised Crime Convention and of the previous Joint Action of 21 December 1998 by making it a criminal offence to participate in a criminal organisation in the Member States of the European Union. Like these instruments, it does not provide a definition of organised crime and has some shortcomings regarding substantive aspects of these concepts. 1. 'criminal organisation' means a structured association, established over a period of time, of more than two persons acting in concert with a view to committing offences which are punishable by deprivation of liberty or a detention order of a maximum of at least four years or a more serious penalty, to obtain, directly or indirectly, a financial or other material benefit; 2. 'structured association' means an association that is not randomly formed for the immediate commission of an offence, nor does it need to have formally defined roles for its members, continuity of its membership, or a developed structure. As the UNODC has pointed out, this definition of the term "criminal organization" is very much in line with that of "organized criminal group" in the UN Organised Crime Convention and the term is subsequently used in Article 2 as a basic component of the description of the offence of "participation in a criminal organization", which determines the scope of application of the special measures prescribed in the following provisions of the Framework Decision. 
Once again, the Framework Decision follows the UN Organised Crime Convention when it foresees in its Article 2 that "each Member State shall take the necessary measures to ensure that one or both of the following types of conduct related to a criminal organisation are regarded as offences: (a) conduct by any person who, with intent and with knowledge of either the aim and general activity of the criminal organisation or its intention to commit the offences in question, actively takes part in the organisation's criminal activities, including the provision of information or material means, the recruitment of new members and all forms of financing of its activities, knowing that such participation will contribute to the achievement of the organisation's criminal activities; (b) conduct by any person consisting in an agreement with one or more persons that an activity should be pursued, which if carried out, would amount to the commission of offences referred to in Article 1, even if that person does not take part in the actual execution of the activity". These two types of conduct of which Member States must recognise at least one as an offence, reflect both the Anglo-Saxon and the continental legal traditions. For the continental the active participation in an organisation's criminal activities is required, with the knowledge of its aim or of its intention to commit crimes. For the AngloSaxon an agreement on the perpetration of crimes without necessarily taking part in committing them is required.

The UNODC Digest of Organised Crime Cases that examines some of the EU Member States cases assesses in particular two cases representing the continental system: France and Italy.In these countries, a list of offences is the keystone of French and Italian legislation on organized crime. In French law, the list is exclusive; it includes the offence of association de malfaiteurs (i.e., any group formed for the preparation of one or more offences punishable by a minimum of five years of imprisonment) only for cases in which the purpose of the association is the commission of another offence included in the list. By contrast, in the Italian system, the offence of "mafiatype criminal association" is included regardless of the offences committed by the association. Thus the limited nature of the list is partially balanced by prosecuting the crime of association: whenever a person is investigated for or charged with participation in a mafia-type association involved in non-listed offences, most or some of the special procedures and measures designed for the listed offences still apply. Moreover, the Italian list encompasses any offence committed for the benefit of, or using the means offered by, a mafia-type association. This legal mechanism allows the special norms to apply to undefined categories of offences when there is no charge of participation in a mafia group but there is proven involvement by this kind of criminal association. So the Italian regime brings together the two legal regimes. As UNODC explains "the frequent adoption of the 'list system' has many possible explanations, but first and foremost is the fact that the criminological characterization of the listed offences enables measures to be tailored to the precise nature of organized crime in a certain country at a certain time, and provides additional justifications for the introduction of new rules. However, the 'list system' suffers serious disadvantage of rigidity, requiring time-consuming and complex legal, and sometimes also institutional, adjustments when organized groups get involved in non-listed crimes or when new crimes arise that are either by their nature or de facto committed by criminal groups. This rigidity can also pose difficulties in dealing with transnational crimes since a restricted scope of application may impede international legal assistance." As UNODC states these difficulties are not necessarily connected to the double criminality rule. It may happen that the offence is also criminalized in the legal system of the country whose assistance is requested, but because the offence falls outside the scope of application of the special measures against organized crime, the requested measure (e.g., controlled delivery) cannot be executed. It is the double criminality principle especially problematic in the area of organised crime because some aspects of the international norms can lead to different conclusions. The first issue concerns the undefined scope of application of the UN Convention, a figure shared by the EU Framework Decision. The Convention and the Framework Decision apply, inter alia, to the open-ended class of serious crime, which includes offences that the Parties/Member States are free to criminalize or not. Therefore, the Convention does not assure double criminality for this class of offences. The EU on the other hand has overcome this problem thanks to the solution offered by Article 5 of the Framework Decision, which has been further strengthened by the European Court of Justice case law on extradition. In its decision in the Mantello case interpreting Article 2(1) and (2) of the Framework Decision on European arrest warrant, the Court accepted the possibility of granting the warrant on offences without verification of the double criminality rule of the crime. Under Article $2(2)$, that rule does not apply in respect of 32 categories of crimes, provided that the issuing Member State punishes those offences by a prison sentence of a maximum of at least three years. Among those offences are included the participation in a criminal organization and environmental crime, including illicit trafficking in endangered animal species and in endangered plant species and varieties. The referring judge argued that this provision of the Framework Decision could contravene the principle of legality. Even though the list of paragraph 2 of Article 2 of the Decision has been much criticized for not containing offences which, as the Spanish Government observes in its notable statement in intervention (paragraph 121), have a serious effect on legal interests in need of special protection in Europe, and there is a requirement that the Member State issuing the arrest warrant must punish those offences by sentences with a particular degree of severity. They 
are offences where the verification of double criminality is regarded as superfluous because the acts concerned are punished in all Member States.

UNODC has said that "exploiting the flexibility of States on the dual criminality requirement could be a solution for mutual assistance, but not for extradition. For both-and by necessity for extradition - universal criminalization of specific conduct via an ad hoc international criminal law treaty remains the chief way out.

Treaty of lisbon

"Communisation" instead of intergovernmental cooperation

The Treaty of Lisbon has been adopted after long discussions and political turbulences. Finally, it is in force since 1 December 2009. Amongst many reforms provided for in the Treaty of Lisbon, reform of the judicial cooperation in criminal matters is perhaps the deepest and the most visible. The Treaty of Lisbon has abolished the abovementioned „third pillar”. The former Article 31 paragraph 1 letter e) TEU has been replaced by the article 83 paragraph 1 Treaty on the Functioning of the European Union [TFEU], which provides as follows: The European Parliament and the Council may, by means of directives adopted in accordance with the ordinary legislative procedure, establish minimum rules concerning the definition of criminal offences and sanctions in the areas of particularly serious crime with a cross-border dimension resulting from the nature or impact of such offences or from a special need to combat them on a common basis. These areas of crime are the following: terrorism, trafficking in human beings and sexual exploitation of women and children, illicit drug trafficking, illicit arms trafficking, money laundering, corruption, counterfeiting of means of payment, computer crime and organised crime. On the basis of developments in crime, the Council may adopt a decision identifying other areas of crime that meet the criteria specified in this paragraph. It shall act unanimously after obtaining the consent of the European Parliament. The transfer of this provision from TEU to TFEU is not only of technical nature. The regulations of TFEU adopt the so called "community method" instead of the hitherto prevailing intergovernmental method.

\section{The ordinary procedure}

The ordinary procedure means the procedure provided for in the article 294 TFEU. The scope of this article does not allow to completely present the ordinary legislative procedure, hence we will limit our considerations to point out the main differences between the new and the old regulations - the European Commission has a monopoly of the right of initiative; - the European Council decides by a qualified majority voting instead of an unanimously voted framework decision; - the European Parliament is involved in the procedure and even has the power to bring a proposal to an end.; - the Court of Justice ensures the uniformity in the interpretation of the Community law; - national parliaments may be involved in the procedure. This change has two main features. First, it is limiting of the sovereign power of the Member States to regulate the criminal matters, e. g. to define types of crimes and to establish penalties. Under the new regulation a simple veto of a state is impossible. Moreover, after 1 January, 2014, it will not even be sufficient to reject a proposal for a directive. Criminal matters were always recognized as one of the most delicate issues regarding the sovereignty of the state. It seems that the authors of the European Constitution and then the Treaty of Lisbon were aware thereof and it was the reason why they established paragraph 3 of the article 83, which will be discussed below. Secondly, the power of governments was restrained and the competence of the European Parliament was extended. It is worth noting that the prerogatives of national parliaments were also enlarged, however in a very limited scope. Under new regulations, the consent of the European Parliament (at least in a silent form) is on the necessity of adopting any directive concerning criminal matters. Such a reform must be welcomed as an attempt to tackle the so called "EU democracy deficit". In criminal matters this deficit is especially sensitive, since the criminal law is the deepest interference in the human freedom. The commonly recognized rule: nullum crimen, nulla poena sine lege (no crime, no punishment without the statute), sometimes known as nullum crimen, nulla poena sine lege parlamentaria (no crime, no punishment without the statute of a parliament), is at least partially fulfilled. The next consequence of transferring criminal matters to the first pillar is a change of the form of the legal instruments. The former framework decisions were replaced by the directives. Obviously the framework decisions adopted before 1 December, 2009 are still in force. Both types of acts seems to be similar. The general rule is that each member state is obliged to adopt provisions in its own legal system to implement the matter regulated in a framework decision or a directive. The main difference is the direct effect. TEU specified that the framework decisions do not have a direct effect. There is no such provision concerning the directives. According to case law of the European Court of Justice, the directives have only a limited direct effect. An individual can only raise an argument stemming from a directive if a state did not implement it or the implementation thereof is incorrect and only provided that the individuals' claim is against a state or its agency30. It is hardly imaginable that an argument concerning a directive on the substantial criminal law could be raised by an individual. This is because such directives are the instruments of a state or/and EU. 
Bearing in mind the traditional function of the penal law as a guarantee for an individual such arguments do not make any sense here, as the EU establishes only minimal rules and any member state can adopt more severe punishments or can criminalize other types of crimes than EU. As a result, the change of the form of the acts will have little impact in practice.

\section{CONCLUSION}

The firm and unequivocal evaluation of the changes introduced by the Lisbon Treaty with relation to harmonisation of penal law constitutes a quite difficult task.

The changes brought about by the Lisbon treaty allow the further unification of the system of substantive law that deals with the crimes considered to be the most challenging for the EU.

The next advantage of the Treaty of Lisbon is changing the form of legal act concerning criminal matters. Directives have been the most popular instruments in the legal heritage of the EC and applying them to criminal matters strengthens the consistency of the common legal system. However, as we have mentioned above, it is hardly possible that these directives will have any direct effect. Hence the crucial point is possibility to force the Member States to implement the directive (Hristov, 2018a, pp.61-67; Hristov, Radulov, lliev, Andreeva, 2010a; Hristov, 2018b, pp. 183-186; Hristov, Ninov, 2018c, pp.316-323; Hristov, Naplatanova, 2018d, pp. 293-315; Hristov, 2017a, pp. 998-1004, Hristov, Georgiev, 2017b, , pp. 110 -113; Hristov, Georgiev, 2017c, , pp. 114-117; Hristov, Glushkov, 2018e, pp.582-588; Hristov, Glushkov, 2018f, pp. 187-193; Hristov, 2017d, pp. 821-829; Madanski, Georgiev, 2017e, pp. 4-13; Madanski, Georgiev, 2017f, pp. 43-51; Terziev, Madanski, Georgiev, 2017g pp. 748-753; Terziev, Madanski, Georgiev, 2017h pp. 743747; Terziev, Madanski, Georgiev, 2017i pp. 923-927; Terziev, Madanski, Georgiev, 2017j, pp. 1051-1055; Terziev, Nichev, Bankov, 2016a, s.189-196; Terziev, Nichev, Bankov, 2016b, s. s.116-134; Terziev, Nichev, Bankov, 2016c, pp.12-21; Terziev, Nichev, Bankov, 2016d, str.119-128; Terziev, Nichev, Bankov, 2016e, str.129-146; Terziev, Nichev, Bankov, 2016e, str.129-146; Terziev, Nichev, Bankov, 2016f, str. 144-185; Terziev, Nichev, Bankov, 2016f, str. 144-185; Terziev, Nichev, Bankov, 2016g, s.413-422; Terziev, Nichev, Bankov, 2016h, str.177-204; Nichev, 2017k, str. 121-128; Nichev, 2017l, pp. 129-135; Kanev, Terziev. 2017m; Kanev, Terziev, 2017n; Terziev, 2017o; Terziev, 2016i; Terziev, 2017p; Terziev, 2017q; Terziev, Vezieva, Arabska, 2016j; Terziev, Manolov, 2016k; Terziev, Minev, Sotirov, Ivanov, 2016l; Terziev, Kanev, 2017r; Terziev, Madanski, 2017s; Terziev, Madanski, 2017t; Terziev, Madanski, 2017u; Terziev, Madanski, Kanev, 2017v; Terziev, Madanski, Kanev, 2017w; Terziev, Madanski, Kanev, 2017x; Terziev, Madanski, Kanev, 2017y; Terziev, Madanski, Kanev, 2017z; Terziev, Nichev, 2016m; Terziev, Nichev, 2017).

\section{REFERENCE LIST}

Hristov, Neno. (2018a). Military Education as Possibility in Bulgaria. IJAEDU- International E-Journal of Advances in Education, Vol. IV, Issue 10, April 2018, pp.61-67.

Hristov, N., Radulov, I., lliev, P., Andreeva, P. (2010a). Prioritization Methodology for Development of Required Operational Capabilities. RTO-MP-SAS-081, 2010.

Hristov, Neno. (2018b). NATO Resilience, Deter and Professional Military Education. Proceedings of INTCESS 2018- 5th International Conference on Education and Social Sciences 5-7 February 2018Istanbul, Turkey, pp. 183-186.

Hristov, N, Ninov, M. (2018c). People's Character As a Prerequisite for the Albanian 'National Delay'. // 5th International Conference on Education, Social Sciences and Humanities, 2-4 July, 2018, ISBN: 978605-82433-3-0 316, pp.316-323.

Hristov, N, Naplatanova, G. (2018d). The Stereotypes of Military Towards Journalists and Work with Embedded Reporters in Missions and Operations Abroad. // 5th International Conference on Education, Social Sciences and Humanities, 2-4 July, 2018 - Dubai, ISBN: 978-605-82433-3-0, pp. 293-315.

Hristov, Neno. (2017a). Bulgarian Experience in the Development of Military Concepts. // IJASOSInternational E-Journal of Advances in Social Sciences, Vol. III, Issue 9, December 2017, pp. 9981004.

Hristov, N., Georgiev, M. (2017b). Offset implementation impact on technology transfer in Bulgaria. // 
International Scientific Journal "Internauka". Izdatel' OOO «Finansovaya Rada Ukrainy», Kiyev, № 10 (32), 2017, pp. 110 -113, ISSN 2520-2057 (Hristov, N., Georgiev, M. Offset implementation impact on technology transfer in Bulgaria. // International Scientific Journal "Internauka". Издатель ООО «Финансовая Рада Украины», Киев, № 10 (32), 2017, pp. 110 -113, ISSN 2520-2057).

Hristov, N., Georgiev, M. (2017c). Offset as an economic operation and a trade practice. // International Scientific Journal “Internauka”. Izdatel' OOO «Finansovaya Rada Ukrainy», Kiyev, № 10 (32), 2017, pp. 114-117, ISSN 2520-2057 (Hristov, N., Georgiev, M. Offset as an economic operation and a trade practice. // International Scientific Journal "Internauka”. Издатель ООО «Финансовая Рада Украины», Киев, № 10 (32), 2017, pp. 114-117, ISSN 2520-2057).

Hristov, N., Glushkov, P. (2018e). Comparative Analysis of the Management Activity Training Of the Cadets, Studying in the Logistic Specializations. // Proceedings of INTCESS2018- 5th International Conference on Education and Social Sciences 5-7 February 2018- Istanbul, Turkey, pp.582-588.

Hristov, N., Glushkov, P. (2018f). Some Aspects Regarding the Display of the Organizational Activity at Work of the Logistic Officers. // Proceedings of INTCESS2018- 5th International Conference on Education and Social Sciences 5-7 February 2018- Istanbul, Turkey, pp.187-193.

Hristov, Neno. (2017d). Policy for Implementation of the Enterprise Architecture as a Tool in Bulgarian Mod. // The University of Sydney, 'History, Problems and Prospects of Development of Modern Civilization' The XX International Academic Congress (Australia, Sydney, 18-20 July 2017) Papers and commentaries Volume XX, ISBN: 978-0-578-84563-7, pp. 821-829.

Madanski, V., Georgiev, M. (2017e). The offset as a specific sort of economic activity. // Scientific journal «Economics and finance». Academic publishing house of the Agricultural University, Priority research areas: Collection of scientific articles, 2017, pp. 4-13, ISBN 978-617-7214-53-2.

Madanski, V., Georgiev, M. (2017f). Study of the effect of offset implementation on technology transfer in the Republic of Bulgaria. // Scientific journal «Economics and finance». Academic publishing house of the Agricultural University, Priority research areas: Collection of scientific articles, 2017, pp. 43-51, ISBN 978-617-7214-53-2.

Terziev, V., Madanski, V., Georgiev, M. (2017g). Offset as an economic operation and a trade practice. // Proceedings of ADVED 2017- 3rd International Conference on Advances in Education and Social Sciences 9-11 October 2017- Istanbul, Turkey. International Organization Center of Academic Research, www.ocerint.org, 2017, pp. 748-753, ISBN: 978-605-82433-0-9.

Terziev, V., Madanski, V., Georgiev, M. (2017h). Offset implementation impact on technology transfer in Bulgaria. // Proceedings of ADVED 2017- 3rd International Conference on Advances in Education and Social Sciences 9-11 October 2017- Istanbul, Turkey .International Organization Center of Academic Research, www.ocerint.org, 2017, pp. 743-747, ISBN: 978-605-82433-0-9.

Terziev, V., Madanski, V., Georgiev, M. (2017i). Offset implementation impact on technology transfer in Bulgaria. // IJAEDU- International E-Journal of Advances in Education, International Organization Center of Academic Research, www.ocerint.org, 3, 2017, N 9, pp. 923-927, e-ISSN: 2411-18.

Terziev, V., Madanski, V., Georgiev, M. (2017j). Offset as an economic operation and a trade practice. // IJAEDU- International E-Journal of Advances in Education, International Organization Center of Academic Research, www.ocerint.org, 3, 2017, N 9, pp. 1051-1055, e-ISSN: 2411-18.

Terziev, V., Nichev, N., Bankov, S. (2016a). Corruption and national security. // Mezhdunarodnyy nauchnnyy zhurnal Inovatsionnaya nauka, №10-3/2016, Chastyakh 3, Ufa, Rossiya, ISSN 2410-6070, s.189-196 (Terziev, V., Nichev, N., Bankov, S. Corruption and national security. // Международный научнный журнал Иновационная наука, №10-3/2016, Частях 3, Уфа, Россия, ISSN 2410-6070, с.189-196).

Terziev, V., Nichev, N., Bankov, S. (2016b). Essence and reasons for the manifestation and basic areas of corruption and government structures for corruption counteraction in Bulgaria. // Sbornik nauchnykh trudov „Novyy vzglyad”: Mezhdunarodnyy nauchnyy vestnik: sbornik nauchnykh trudov. Vypusk 15 / Pod obshch. red. S.S. Chernova. - Novosibirsk: Izdatel'stvo TSRNS, 2016. - 166 s., ISBN 978-500068-714-7, s.116-134 (Terziev, V., Nichev, N., Bankov, S. Essence and reasons for the manifestation and basic areas of corruption and government structures for corruption counteraction in Bulgaria. // Сборник научных трудов „Новый взгляд”: Международный научный вестник: сборник научных трудов. Выпуск 15 / Под общ. ред. С.С. Чернова. - Новосибирск: Издательство ЦРНС, 2016. - 166 c., ISBN 978-5-00068-714-7, c.116-134). 
Terziev, V., Nichev, N., Bankov, S. (2016c). National security of the republic of Bulgaria. // Science and practice: Collection of scientific articles. Thoroe-Bowker, Melbourne, Australia, 2016, ISBN 978-09942661-3-2, pp.12-21.

Terziev, V., Nichev, N., Bankov, S. (2016d). Tipichni modeli na razsledvanena koruptsiyata sred politseyski sluzhiteli. // Sbornik dokladi: Godishna universitetska nauchna konferentsiya, 20-21 oktomvri 2016 g., NVU „Vasil Levski“ - Veliko Tarnovo., Nauchno napravlenie „Sotsialni, stopanski i pravni nauki“, 7, 2016, ISSN 1314-1937, str.119-128 (Терзиев, В., Ничев, Н., Банков, С. Типични модели на разследванена корупцията сред полицейски служители. // Сборник доклади: Годишна университетска научна конфреренция, 20-21 октомври 2016 г., НВУ „Васил Левски“ - Велико Търново., Научно направление „Социални, стопански и правни науки“, 7, 2016, ISSN 1314-1937, стр.119-128).

Terziev, V., Nichev, N., Bankov, S. (2016e). Nakazatelno pravni aspekti na koruptsiyata i ustanoveni praktiki v Balgariya. // Sbornik dokladi: Godishna universitetska nauchna konferentsiya, 20-21 oktomvri 2016 g., NVU „Vasil Levski“ - Veliko Tarnovo., Nauchno napravlenie „Sotsialni, stopanski i pravni nauki“, 7, 2016, ISSN 1314-1937, str.129-146 (Терзиев, В., Ничев, Н., Банков, С. Наказателно правни аспекти на корупцията и установени практики в България. // Сборник доклади: Годишна университетска научна конфреренция, 20-21 октомври 2016 г., НВУ „Васил Левски“ - Велико Търново., Научно направление „Социални, стопански и правни науки“, 7, 2016, ISSN 1314-1937, стр.129-146).

Terziev, V., Nichev, N., Bankov, S. (2016f). Prilozhenie na efektivna metodika na razsledvane na koruptsiyata sred politseyskite sluzhiteli v Balgariya. // Godishnik na NVU „Vasil Levski“, NVU „Vasil Levski“- Veliko Tarnovo, Izdatelski kompleks na NVU „Vasil Levski”, 2015, ISSN 1312-6148, str.144185 (Терзиев, В., Ничев, Н., Банков, С. Приложение на ефективна методика на разследване на корупцията сред полицейските служители в България. // Годишник на НВУ „Васил Левски“, НВУ „Васил Левски“- Велико Търново, Издателски комплекс на НВУ „Васил Левски”, 2015, ISSN 1312-6148, стр.144-185).

Terziev, V., Nichev, N., Bankov, S. (2016g). Razrabotvane na metodika na razsledvane na koruptsiyata sred politseyskite sluzhiteli v Balgariya. II XI Mezhdunarodnoy nauchnoy konferentsii "Innovatsii v tehnologiyah i obrazovanii“, 18-19 Marta 2016 g., Sbornik statey: chasty 3, Belovo- Veliko-tayrnovo, 2016, Kuzbasskiy gosudarstvennayy tehnicheskiy universitet imeni T.F. Gorbacheva Velikotayrnovskiy universitet im. Svyatayh. Kirilla i Mefodiya Filial KuzGTU v g. Belovo Vaysshaya shkola agrobiznesa i razvitiya regionov, Plovdiv, 2016, s.413-422, ISBN 978-5-906888-03-7 (Терзиев, В., Ничев, Н., Банков, С. Разработване на методика на разследване на корупцията сред полицейските служители в България. // XI Международной научной конференции „Инновации в технологиях и образовании“, 18-19 Марта 2016 г., Сборник статей: часть 3, Белово- Велико-тырново, 2016, Кузбасский государственный технический университет имени Т.Ф. Горбачева Великотырновский университет им. Святых. Кирилла и Мефодия Филиал КузГТУ в г. Белово Высшая школа агробизнеса и развития регионов, Пловдив, 2016, с.413-422, ISBN 978-5-906888-03-7).

Terziev, V., Nichev, N., Bankov, S. (2016h). Prilozhenie na efektivna metodika na razsledvane na koruptsiyata sred politseyskite sluzhiteli v Balgariya. // Sbornik dokladi: Parva nauchna konferentsiya po sotsialno predpriemachestvo. Saveti, umeniya i instrumenti za konsultirane na sotsialnite predpriemachi, Proekt : Umeniya za biznes konsultanti v oblastta na sotsialnoto predpriemachestvo, International scientific conference 29 September 2016, Plovdiv, Bulgaria, Agraren Universitet Plovdiv, 2016, ISBN 978-954-517-249-6 (CD), ISBN 978-954-517-250-2 (Print), str.177-204 (Терзиев, В., Ничев, Н., Банков, С. Приложение на ефективна методика на разследване на корупцията сред полицейските служители в България. // Сборник доклади: Първа научна конференция по социално предприемачество. Съвети, умения и инструменти за консултиране на социалните предприемачи, Проект : Умения за бизнес консултанти в областта на социалното предприемачество, International scientific conference 29 September 2016, Plovdiv, Bulgaria, Аграрен Университет Пловдив, 2016, ISBN 978-954-517-249-6 (CD), ISBN 978-954-517-250-2 (Print), стр.177-204).

Nichev, N. (2017k). Ofsetna politika na stranite ot Evropeyskiya Sayuz. Spisanie za nauka „Novo znanie”, Akademichno izdatelstvo „Talant“, Visshe uchilishte po agrobiznes i razvitie na regionite, Plovdiv, Vol 6, No 1, 2017, str. 121-128, ISSN 2367-4598 (Online), ISSN 1314-5703 (Print) (Ничев, Н. Офрсетна политика на страните от Европейския Съюз. Списание за наука „Ново знание”, Академично издателство „Талант“, Висше училище по агробизнес и развитие на регионите, Пловдив, Vol 6 , No 1, 2017, стр. 121-128, (Online) ISSN 2367-4598, (Print) ISSN 1314-5703). 
Nichev, N. (2017l). Perspektivi za izpolzvane na ofsetnite sdelki. Spisanie za nauka „Novo znanie”, Akademichno izdatelstvo „Talant“, Visshe uchilishte po agrobiznes i razvitie na regionite - Plovdiv, Vol 6, No 1, 2017: pp. 129-135, (Online) ISSN 2367-4598, (Print) ISSN 1314-5703 (Ничев, Н. Перспективи за използване на офсетните сделки. Списание за наука „Ново знание”, Академично издателство „Талант“, Висше училище по агробизнес и развитие на регионите Пловдив, Vol 6, No 1, 2017: pp. 129-135, (Online) ISSN 2367-4598, (Print) ISSN 1314-5703).

Kanev, D.,Terziev. V. (2017m). Behavioral economics: development, condition and perspectives. // IJASOSInternational E-Journal of Advances in Social Sciences, Vol. III, Issue 8, e-ISSN: 2411-183X.

Kanev, D.,Terziev. V. (2017n). Behavioral economics: development, condition and perspectives. // Proceedings of SOCIOINT 2017- 4th International Conference on Education, Social Sciences and Humanities 10-12 July 2017- Dubai, UAE, ISBN: 978-605-82433-1-6.

Sotirov, B., Terziev, V. (2015a). Predizvikatelstva i perspektivi pred obuchenieto po tehnologichni distsiplini. // Parva mezhdunarodna nauchna konferentsiya „Predizvikatelstva pred savremennite organizatsii, svarzani s postigane na ustoychivost - znanie i inovatsii v upravlenieto i funktsioniraneto“,Plovdiv. ISBN 978-619-7246-04-9 (DVD), ISBN 978-619-7246-06-3 (e-book).

Sotirov, B., Terziev, V. (2015b). Challenges and perspectives to the training in technological subjects. // Book of Abstracts: First International Scientific Conference „Sustainability Challenges in Modern Organizations - Knowledge \& Innovation in Management \& Operation", ISBN 978-619-7246-03-2 (DVD), ISBN 978-619-7246-05-6 (e-book)

Terziev. V. (20170). National security of the republic of Bulgaria. // The Chinese Journal of International Politics, №1(10), ISSN 1750-8916.

Terziev. V. (2016i). Human resource management systems in security and defense: social policies for social activities. // XXXII Mezhdunarodnaya nauchno-prakticheskaya konferentsiya, Evraziyskiy soyuz uchenayh (ESU), Ezhemesyachnayy nauchnayy zhurnal № 12 (33)/ 2016 Chasty 1, Moskva 30.12.2016g., ISSN 2411-6467.

Terziev. V. (2017p). Entry Opportunities in the Bulgarian Military - Educational System and Ensuring of Civil Rights. // 3rd Central and Eastern European LUMEN International Scientific Conference New Approaches in Social and Humanistic Sciences 8-10 June 2017 | Chisinau, Republic of Moldova, ISBN: 978-973-166-461-3.

Terziev. V. (2017q). National security of the republic of Bulgaria. // International Journal of Management and Applied Science, Volume-3, Issue-4, ISSN: 2394-7926.

Terziev, V., Vezieva. V., Arabska, A. (2016j). Balgarskite universiteti i vazmozhnostite na Operativna programa „Nauka i obrazovanie za inteligenten rastezh". // Mezhdunarodna nauchna konferentsiya „Obrazovanie, nauka, ikonomika i tehnologii“ 23-24 yuni 2016 g. Akademichno spisanie „Upravlenie i obrazovanie“ Tom XII(1) 2016, ISSN 1312-6121.

Terziev, V., Manolov.D. (2016k). Sazdavane na dobra organizatsionna sreda za nauchnoizsledovatelska deynost (Creation of good organizational environment for scientific research activity), Aktual'nyye problemy globalizatsii. // Saloniki, Gretsiya (Actual problems of globalization, August 29, 2016, Thessaloniki, Greece), Scientific journal „ECONOMICS AND FINANCE“, Actual problems of globalization - Collection of scientific articles, ISBN 978-617-7214-34-1.

Terziev, V., Minev, R., Sotirov, B., Ivanov, K. (2016I). Vazmozhnosti za izgrazhdane na tsentar za kompetentnost $v$ Severen tsentralen rayon na Republika Balgariya. // Godishna universitetska nauchna konferentsiya, 20-21 oktomvri 2016 g. NVU „Vasil Levski“- Veliko Tarnovo. Sbornik dokladi tom 2, Nauchni napravleniya „Prirodomatematicheski nauki” i „Tehnicheski nauki”, ISSN 1314-1937.

Terziev. V., Kanev, D. (2017r). Education and Behavioural Failures. // Proceedings of ADVED 2017- 3rd International Conference on Advances in Education and Social Sciences 9-11 October 2017- Istanbul, Turkey, ISBN: 978-605-82433-0-9.

Terziev, V, Madanski, V. (2017s). Development of military education system in Bulgaria (Razvitie na voennoobrazovatelnata sistema $v$ Balgariya). // Topical questions of contemporary science, United States of America 2017, ISBN 978-0-9988732-1-3.

Terziev, V, Madanski, V. (2017t). Guidelines for development of military education system in Bulgaria (Nasoki za razvitie na voennoobrazovatelnata sistema na Balgariya). // Topical questions of contemporary science, United States of America 2017, ISBN 978-0-9988732-1-3. 
Terziev, V, Madanski, V. (2017u). Guidelines for development of military education system in Bulgaria. // Proceedings of the VII International Academic Congress "Fundamental and Applied Studies in EU and CIS Countries" (United Kingdom, Cambridge, England, 26-28 February 2017). Volume VII. Cambridge University Press, 2017, ISBN: 978-0-875-83597-4.

Terziev, V, Madanski, V., Kanev, D. (2017v). Entry opportunities in the bulgarian military-educational system and ensuring of civil rights. // Proceedings of SOCIOINT 2017- 4th International Conference on Education, Social Sciences and Humanities 10-12 July 2017- Dubai, UAE, ISBN: 978-605-82433-1-6.

Terziev, V, Madanski, V., Kanev, D. (2017w). Entry opportunities in the bulgarian military-educational system and ensuring of civil rights. // IJAEDU- International E-Journal of Advances in Education, Vol. 3, Issue 8, August 2017, e-ISSN:2411-1821.

Terziev, V, Madanski, V., Kanev, D. (2017x). Entry opportunities in the Bulgarian military-educational system. // Sport, Education and Society, Issue 8 (2), Volume 22. Taylor \& Francis, Print ISSN: 1357-3322 Online ISSN: 1470-1243.

Terziev, V, Madanski, V., Kanev, D. (2017y). Condition and capabilities of the military-educational system of the Republic of Bulgaria. // Sport, Education and Society, Issue 8 (2), Volume 22. Taylor \& Francis, Print ISSN: 1357-3322 Online ISSN: 1470-1243.

Terziev, V, Madanski, V., Kanev, D. (2017z). Directions for improvement of the military-educational system and its contribution for strengthening national security and the defence of the country. // Sport, Education and Society, Issue 8 (2), Volume 22. Taylor \& Francis, Print ISSN: 1357-3322 Online ISSN: 1470-1243.

Terziev, V., N.Nichev. $(2016 \mathrm{~m})$. Ikonomicheski harakteristiki na ofestnite sdelki s otrbranitelni produkti. // Scientific journal „Economics and Finance”, Problems of development modern science: Theory and practice - Collection of scienfic articles, pp.101-106.

Terziev. V., N.Nichev. (2017). Osnovni harakteristiki na kompensaciite v tyrgoviqta s otbrana. // Proceedings of SOCIOINT 2017- 4th International Conference on Education, Social Sciences and Humanities, pp.661-666. 